University of Nebraska - Lincoln

DigitalCommons@University of Nebraska - Lincoln

\title{
A method to detect oxidative stress by monitoring changes in the extracellular antioxidant capacity in plant suspension cells
}

\author{
C. Jacyn Baker \\ United States Department of Agriculture, jacyn.baker@ars.usda.gov \\ Norton M. Mock \\ United States Department of Agriculture
}

Follow this and additional works at: https://digitalcommons.unl.edu/usdaarsfacpub

Part of the Agricultural Science Commons

Baker, C. Jacyn and Mock, Norton M., "A method to detect oxidative stress by monitoring changes in the extracellular antioxidant capacity in plant suspension cells" (2004). Publications from USDA-ARS / UNL Faculty. 335.

https://digitalcommons.unl.edu/usdaarsfacpub/335

This Article is brought to you for free and open access by the U.S. Department of Agriculture: Agricultural Research Service, Lincoln, Nebraska at DigitalCommons@University of Nebraska - Lincoln. It has been accepted for inclusion in Publications from USDA-ARS / UNL Faculty by an authorized administrator of DigitalCommons@University of Nebraska - Lincoln. 


\title{
A method to detect oxidative stress by monitoring changes in the extracellular antioxidant capacity in plant suspension cells ${ }^{\text {is }}$
}

\author{
C. Jacyn Baker*, Norton M. Mock \\ Molecular Plant Pathology Laboratory, US Department of Agriculture, Plant Sciences Institute, Bldg 004 Rm. 119, Beltsville MD 20705, USA
}

Accepted 7 September 2004

\begin{abstract}
Detection of $\mathrm{H}_{2} \mathrm{O}_{2}$ in the supernatant of plant suspension cells is often used to indicate the time and extent of the oxidative burst during interactions with either bacteria or pathogen-related elicitors. We have found that suspensions of plant cells, depending on conditions, may produce considerable levels of extracellular phenolics that can function as antioxidants and prevent or suppress the detection of $\mathrm{H}_{2} \mathrm{O}_{2}$. These compounds can be used as substrates by extracellular peroxidases to scavenge stoichiometric amounts of $\mathrm{H}_{2} \mathrm{O}_{2}$. When this occurs during plant/pathogen interactions it can mask both the timing and extent of the oxidative burst if detection of free $\mathrm{H}_{2} \mathrm{O}_{2}$ is the only technique used. We have developed a chemiluminescent technique that will account for the $\mathrm{H}_{2} \mathrm{O}_{2}$ scavenged by these extracellular metabolites. A known quantity of $\mathrm{H}_{2} \mathrm{O}_{2}$ is added to samples and allowed to react with the extracellular antioxidants. The amount of $\mathrm{H}_{2} \mathrm{O}_{2}$ that remains is then determined by adding luminol to the sample and measuring luminol-dependent-chemiluminescence. The difference between treated and control samples represents the amount of $\mathrm{H}_{2} \mathrm{O}_{2}$ that has been produced by the cells in response to the treatment. We have found that this technique provides a better estimate of both the magnitude and timing of the oxidative burst in bacterial/suspension cell systems.

Published by Elsevier Ltd.
\end{abstract}

Keywords: Reactive oxygen; Hydrogen peroxide; Pseudomonas syringae; Nicotiana tabacum L. cv. Hicks; Solanum tuberosum cv. Kennebec; Phenolics

\section{Introduction}

Plant/bacterial model systems incorporating suspension cells continue to provide unique insights into plant pathogenic interactions $[4-6,8-10]$. They have been especially valuable in gaining a better understanding of the role of oxidative metabolism in pathogenesis where reactive oxygen species and other metabolites are often transient and/or difficult to detect. For many years the oxidative burst has been detected by assaying for the appearance of $\mathrm{H}_{2} \mathrm{O}_{2}$ using sensitive chemiluminescent or fluorescent assays that linked directly to the free $\mathrm{H}_{2} \mathrm{O}_{2}$ present in the samples.[11-13,15]

\footnotetext{
Mention of a trade name, proprietary product, or vendor does not constitute a guarantee of the product by the United States Department of Agriculture and does not imply its approval to the exclusion of other vendors that may also be suitable.

* Corresponding author. Tel.: +1 301504 5617; fax: + 13015045449.

E-mail address: bakerc@ba.ars.usda.gov (C.J. Baker).
}

Recently we found that suspensions of plant cells that are transferred to fresh assay buffer, produce substantial levels of extracellular antioxidants that can attenuate and often completely mask the oxidative burst in plant cells treated with bacterial pathogens [2]. It appears that as the oxidative burst occurs, the $\mathrm{H}_{2} \mathrm{O}_{2}$ associated with the event is continually scavenged by the cell wall peroxidases using the extracellular antioxidants as reductants. Unlike the cytoplasmic antioxidant mechanisms, which have considerable reserves of NADH or NADPH to regenerate antioxidants, the extracellular antioxidant mechanisms appear to be limited to the finite extracellular pool of ascorbic acid and phenolic antioxidants. The ascorbic acid in the cell wall region is capable of regenerating oxidized phenolics. There is evidence that the oxidized form of ascorbic acid, dehydroascorbate, is shuttled back to the cytoplasm and regenerated, however, this is a time dependent process $[16,17,19,20]$.

We have developed a new technique that, (1) quantifies the constitutive and induced production of extracellular 
antioxidants by cell suspensions, and (2) provides a more complete estimation of oxidative events in suspension cells by accounting for reactive oxygen that has been scavenged by the extracellular antioxidants. In brief, a known amount of exogenous $\mathrm{H}_{2} \mathrm{O}_{2}$ is added to samples, allowed to react with the available extracellular antioxidant, and finally the amount of $\mathrm{H}_{2} \mathrm{O}_{2}$ that remains is determined. In untreated or control samples, the exogenous $\mathrm{H}_{2} \mathrm{O}_{2}$ consumed is directly related to the amount of extracellular antioxidant present. In treated samples that have undergone an oxidative burst, a portion of the extracellular antioxidants will have been oxidized and less exogenous $\mathrm{H}_{2} \mathrm{O}_{2}$ will be consumed by these samples. We have found this assay to give a more accurate estimation of the magnitude of the oxidative response of plants cells to pathogens and pathogen-related elicitors.

\section{Materials and methods}

\subsection{Chemicals}

Horseradish peroxidase (P-8250, purchased in units; one unit will oxidize $1 \mu \mathrm{mol}$ of $2,2^{\prime}$ azino-bis (3-ethylbenzthiazoline-6-sulfonic acid) $\min ^{-1}$ as described by Sigma), guaiacol (G-5502), hydrogen peroxide (H1009) and luminol (5-amino-2,3-dihydro-1,4-phthalazinedione, A8511) were purchased from Sigma-Aldrich Chemicals Inc. (St Louis, MO, USA).

\subsection{Plant material}

Suspension cells of tobacco (Nicotiana tabacum L. cv. Hicks) and potato tuber (Solanum tuberosum cv. Kennebec) were maintained as previously described [2] except that tobacco callus and suspension cells were maintained on MS media (supplemented with $200 \mathrm{mg} \mathrm{l}^{-1} \mathrm{KH}_{2} \mathrm{PO}_{4}, 0.2 \mathrm{mg}^{-1}$ 2,4-D and $0.1 \mathrm{mg} \mathrm{l}^{-1}$ kinetin). Tobacco cultures, $10 \mathrm{ml}$, were transferred to $80 \mathrm{ml}$ fresh media every 4 days. Potato cultures, $13 \mathrm{ml}$, were transferred to $80 \mathrm{ml}$ fresh media every 7 days. Routinely, 2-day-old tobacco cells and 5-day-old potato cells were used for experiments. Cells were washed and suspended in assay buffer, containing $0.5 \mathrm{mM} \mathrm{CaCl}_{2}$, $0.5 \mathrm{mM} \mathrm{K}_{2} \mathrm{SO}_{4}, 175 \mathrm{mM}$ mannitol and $0.5 \mathrm{mM}$ MES (pH 6) with a final cell density of $0.05 \mathrm{~g} \mathrm{ml}^{-1}$. Cell suspensions, $25 \mathrm{ml}$, contained in $50 \mathrm{ml}$ beakers were equilibrated for $0.5 \mathrm{~h}$ in a rotary water bath shaker set at $27^{\circ} \mathrm{C}$ and $180 \mathrm{rpm}$ for tobacco cells or $200 \mathrm{rpm}$ for potato cells. Treatments were added directly to the suspensions. All experiments were preformed twice with at least two replicates per treatment.

\subsection{Bacterial preparations}

Cultures of Pseudomonas syringae pv. syringae 61 were maintained as previously described [1]. Isolate WT $(\mathrm{HR}+)$ causes a hypersensitive reaction when infiltrated into tobacco and potato leafs. Isolate B7 ( $\mathrm{HR}-)$ is a Tn5 insertion mutant that does not induce a hypersensitive response [3]. Bacterial cultures were grown for $20 \mathrm{~h}$ in Kings B broth, centrifuged, washed and suspended in deionized water. Based on optical density, the concentration of the suspension was adjusted with water so that addition of about $200 \mu \mathrm{l}$ of the bacterial suspension to plant cell suspensions would result in $2 \times 10^{7} \mathrm{cfu} \mathrm{m}^{-1}$. Bacterial concentrations in cell suspensions were verified periodically by dilution plating.

\subsection{Extracellular hydrogen peroxide assay}

The luminol-dependent-chemiluminescent assay was used to detect extracellular $\mathrm{H}_{2} \mathrm{O}_{2}$ [11]. Using a wide-bore pipette, $0.45 \mathrm{ml}$ samples of treated or untreated suspension cells were dispensed into tubes, and placed into a EG\&G Berthold Autolumat 953 luminometer (Bad Wildbad, Germany). A stock solution was prepared containing horseradish peroxidase, 28.8 units $\mathrm{ml}^{-1}$, and luminol, $1.7 \mathrm{mM}$, in $50 \mathrm{ml}$ of $1 \mathrm{M}$ sodium phosphate, $\mathrm{pH} 7$. As each sample was ready to be assayed, the luminometer added $50 \mu \mathrm{l}$ of the stock solution for a final concentration of $2.88 \mathrm{U} \mathrm{ml}^{-1}$ of peroxidase and $170 \mu \mathrm{M}$ luminol. Chemiluminescence was recorded immediately as relative light units (RLU) every $0.1 \mathrm{~s}$ for $20 \mathrm{~s}$. Under the standard conditions described here the peak height is proportional to the concentration of $\mathrm{H}_{2} \mathrm{O}_{2}$ in the sample. Standard curves were prepared with dilutions of $\mathrm{H}_{2} \mathrm{O}_{2}$ in assay buffer.

\subsection{Extracellular antioxidant assay}

The extracellular antioxidant capacity of cell suspensions was estimated by determining the amount of exogenous $\mathrm{H}_{2} \mathrm{O}_{2}$ consumed by samples. Because the antioxidant mechanism is rapid under the conditions described, it could be carried out using a modification of the luminoldependent-chemiluminescent assay described above. A stock reagent of $\mathrm{H}_{2} \mathrm{O}_{2}$ contained 200 or $500 \mu \mathrm{M} \mathrm{H}_{2} \mathrm{O}_{2}$ in assay buffer for potato or tobacco samples, respectively. The $\mathrm{H}_{2} \mathrm{O}_{2}$ reagent, $50 \mu \mathrm{l}$, was automatically added to suspension samples, $0.4 \mathrm{ml}$, in the luminometer $4.5 \mathrm{~s}$ prior to the peroxidase/luminol reagent, $50 \mu \mathrm{l}$. This extra time was sufficient for the $\mathrm{H}_{2} \mathrm{O}_{2}$ to react with endogenous cell wall peroxidase and the extracellular antioxidant. The amount of extracellular antioxidant can be estimated by calculating the difference in RLU between controls and treatments. Standard curves were prepared with dilutions of $\mathrm{H}_{2} \mathrm{O}_{2}$ in assay buffer.

When this assay is applied to an untested cell line, preliminary assays with untreated control cells need to be conducted. First, the amount of exogenous $\mathrm{H}_{2} \mathrm{O}_{2}$ that is required to completely oxidize the extracellular antioxidants needs to be determined empirically. We have found it best to have at least $10 \mu \mathrm{M} \mathrm{H}_{2} \mathrm{O}_{2}$ in excess at the end of 
the monitoring period. If the exogenous $\mathrm{H}_{2} \mathrm{O}_{2}$ is completely consumed the amount of antioxidant will be underestimated.

\subsection{Endogenous extracellular peroxidase assay}

Much of the extracellular peroxidase activity of these cell suspensions was associated with the cell wall. This assay attempts to estimate the total extracellular peroxidase activity in cell suspensions. Using a wide-bore pipette, $0.5 \mathrm{ml}$ samples of cell suspensions were added to beakers containing: $9.1 \mathrm{ml}$ sodium phosphate buffer, $50 \mathrm{mM} \mathrm{pH} 6$; $0.2 \mathrm{ml}$ guaiacol, $0.4 \mathrm{mM} ; 0.2 \mathrm{ml} \mathrm{H}_{2} \mathrm{O}_{2}, 0.4 \mathrm{mM}$. The reaction mixtures were shaken in a water bath, $27^{\circ} \mathrm{C}$, for a $15 \mathrm{~min}$ period. Aliquots were removed periodically, filtered through miracloth to remove particles, and their absorbance determined on a Beckman DU 650 spectrophotometer at $470 \mathrm{~nm}$. The linear rate of increase in absorbance, $\mathrm{OD}_{470} \mathrm{~min}^{-1}$, was used to monitor changes in peroxidase activity over time.

\section{Results and discussion}

A previous study demonstrated that cell suspensions of tobacco and potato produced extracellular phenolics that were able to react with $\mathrm{H}_{2} \mathrm{O}_{2}$ using cell wall bound peroxidase [2]. We will first show examples of how the technique reported here can be used to quantify both the production of these phenolics as well as the oxidative events that oxidize these phenolics. Subsequently we describe the critical parameters that should be considered in using this technique or adapting it to other cell systems.

\subsection{Monitoring antioxidant capacity during tobacco/bacterial interactions}

Changes in the extracellular antioxidant capacity of tobacco suspension cells either untreated or treated with $P$. syringae pv. syringae strains were followed over a $6 \mathrm{~h}$ period (Fig. 1). Hydrogen peroxide, $50 \mu \mathrm{M}$, was added to samples to react with the extracellular antioxidants and subsequently, additional peroxidase and luminol were added to react with the remaining $\mathrm{H}_{2} \mathrm{O}_{2}$. The peak chemiluminescence was recorded and by comparison to a standard curve, the approximate amount of $\mathrm{H}_{2} \mathrm{O}_{2}$ that had reacted with the extracellular antioxidant was determined (Fig. 1A). Therefore, as the extracellular antioxidants increase and react with more of the added $\mathrm{H}_{2} \mathrm{O}_{2}$, the chemiluminescence decreases. Untreated tobacco cells began accumulating extracellular antioxidants after about $1.5 \mathrm{~h}$ and by $6 \mathrm{~h}$ the concentration was sufficient to react with nearly $35 \mu \mathrm{M} \mathrm{H}_{2} \mathrm{O}_{2}$. Treatment of the tobacco cells with strain B7 (HR-), $0.2 \times 10^{7} \mathrm{cfu} \mathrm{ml}^{-1}$, increased the antioxidant capacity to nearly $40 \mu \mathrm{M} \mathrm{H}_{2} \mathrm{O}_{2}$ by $6 \mathrm{~h}$, slightly more than untreated cells. We have found that this induction of extracellular phenolics varies with the bacterial

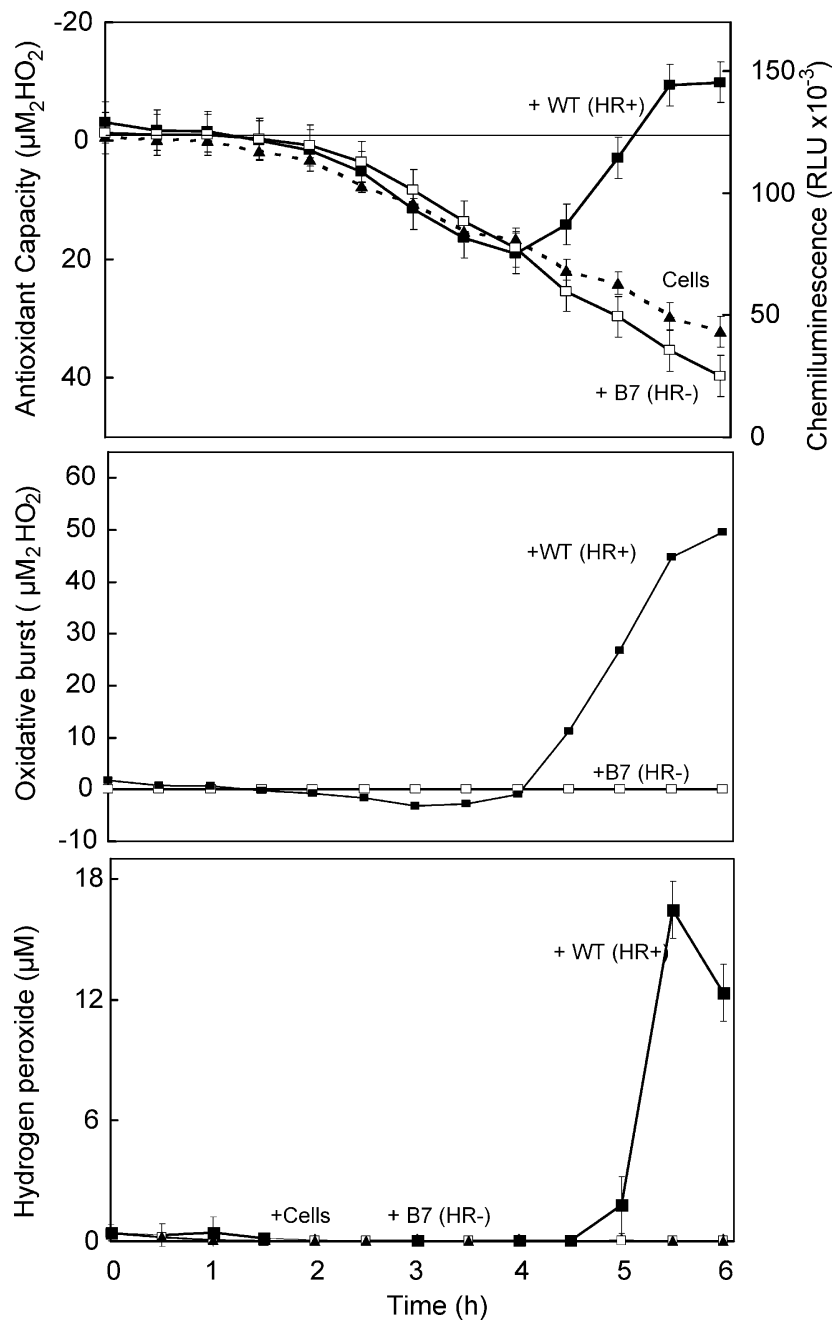

Fig. 1. Monitoring extracellular oxidative metabolism in tobacco suspension cells, $0.05 \mathrm{~g} \mathrm{ml}^{-1}$, treated with Pseudomonas syringae pv. syringae strains, $2 \times 10^{7} \mathrm{cfu} \mathrm{ml}^{-1}$. (A) Determination of the extracellular antioxidant capacity in $0.4 \mathrm{ml}$ samples by addition of $50 \mu \mathrm{M}$ hydrogen peroxide to suspension samples and measurement of the unreacted $\mathrm{H}_{2} \mathrm{O}_{2}$ by luminoldependent chemiluminescence. Chemiluminescence is expressed in relative light units (RLU). The concentration of $\mathrm{H}_{2} \mathrm{O}_{2}$ that remains is determined using a standard curve, and subtracted from the initial concentration of $50 \mu \mathrm{M}$ to determine the antioxidative capacity of the sample. Antioxidant capacity is expressed in $\mu \mathrm{M} \mathrm{H} \mathrm{H}_{2} \mathrm{O}_{2}$ equivalents. (B) Detection of the oxidative stress caused by the $P$. syringae pv. syringae strain WT $(\mathrm{HR}+)$ using strain B7 $(\mathrm{HR}-)$ as a control. The difference in antioxidant capacity between these treatments provides an estimate of the antioxidant concentration consumed by the oxidative burst in strain WT $(\mathrm{HR}+)$ treatments. Units are expressed in $\mu \mathrm{M} \mathrm{H}_{2} \mathrm{O}_{2}$ equivalents. (C) Direct detection of free extracellular $\mathrm{H}_{2} \mathrm{O}_{2}$ in $0.45 \mathrm{ml}$ samples using luminoldependent-chemiluminescence. See Section 2 for details.

concentration (unpublished data). Cells treated with strain WT $(\mathrm{HR}+)$ behaved similarly to strain B7 $(\mathrm{HR}-)$ until about $4 \mathrm{~h}$ when the antioxidant capacity decreased and became negative (prooxidative) by $5-6 \mathrm{~h}$. This indicated that $\mathrm{H}_{2} \mathrm{O}_{2}$ was being produced and by $5 \mathrm{~h}$ it reached a level greater than the extracellular antioxidants, therefore the amount of $\mathrm{H}_{2} \mathrm{O}_{2}$ detected was greater than the exogenous $\mathrm{H}_{2} \mathrm{O}_{2}$ added to the sample. Because bacteria-treated cells 
produce higher levels of extracellular antioxidants, the difference in antioxidant capacity between the two bacterial strains, rather than untreated cells, is a better indication of the magnitude of the oxidative burst (Fig. 1B). By $6 \mathrm{~h}$ the oxidative burst reached the equivalent of $50 \mu \mathrm{M} \mathrm{H}_{2} \mathrm{O}_{2}$ per sample.

Free $\mathrm{H}_{2} \mathrm{O}_{2}$ was detected in samples after $5 \mathrm{~h}$ by a different chemiluminescent technique, which does not add exogenous $\mathrm{H}_{2} \mathrm{O}_{2}$ (Fig. 1C). This coincided with the approximate time where antioxidant capacity is zero (Fig. 1A) confirming that the extracellular antioxidants have been oxidized and any new production of extracellular phenolics is not able to completely scavenge newly produced $\mathrm{H}_{2} \mathrm{O}_{2}$.

\subsection{Monitoring antioxidant capacity during potato/bacterial interactions}

Changes in the extracellular antioxidant capacity of potato suspension cells treated with $P$. syringae pv. syringae strains were generally similar to the results of tobacco except that less antioxidant accumulated (Fig. 2). Because the antioxidant capacity was lower, only $20 \mu \mathrm{M} \mathrm{H}_{2} \mathrm{O}_{2}$ was added exogenously to potato samples. Untreated potato cells started accumulating extracellular antioxidants immediately and by $6 \mathrm{~h}$ produced levels sufficient to react with $10 \mu \mathrm{M}$ $\mathrm{H}_{2} \mathrm{O}_{2}$ (Fig. 2A). Cells treated with either strain of $P$. syringae pv. syringae did not accumulate extracellular antioxidants until $1-1.5 \mathrm{~h}$ after treatment. Comparison of these samples with untreated cells suggested that a small oxidative event had occurred, coincident with the addition of the bacteria, and oxidized extracellular phenolics during the first $2 \mathrm{~h}$ period preventing their accumulation (Fig. $2 \mathrm{~A}$ and B). After about $2 \mathrm{~h}$, cells treated with strain B7 (HR-) increased in antioxidant capacity at a faster rate than untreated cells and reached nearly $20 \mu \mathrm{M}$ by $6 \mathrm{~h}$. Cells treated with strain WT $(\mathrm{HR}+)$ underwent a second oxidative event equivalent to about $20 \mu \mathrm{M} \mathrm{H}_{2} \mathrm{O}_{2}$, after 5-6 h, when compared to B7 ( HR - ) treated cells.

Free $\mathrm{H}_{2} \mathrm{O}_{2}$ could be detected during the second oxidative burst using the luminol dependent direct detection technique without exogenous $\mathrm{H}_{2} \mathrm{O}_{2}$ (Fig. 2C). The $\mathrm{H}_{2} \mathrm{O}_{2}$ was detected over the entire period of the oxidative burst, whereas in tobacco, it was detected only after all the extracellular phenolics had been oxidized. Two factors may contribute to this earlier detection of free $\mathrm{H}_{2} \mathrm{O}_{2}$ in potato cells. Potato cells have lower endogenous peroxidase activity (discussed below) and lower concentrations of extracellular phenolics. These two factors directly contribute to a lower on-going insitu rate of scavenging endogenous $\mathrm{H}_{2} \mathrm{O}_{2}$ by potato cells compared to tobacco cells. This lower rate of scavenging appears to increase the sensitivity of the $\mathrm{H}_{2} \mathrm{O}_{2}$ assay in potato by allowing the exogenous luminol and peroxidase to better compete for the endogenous $\mathrm{H}_{2} \mathrm{O}_{2}$.

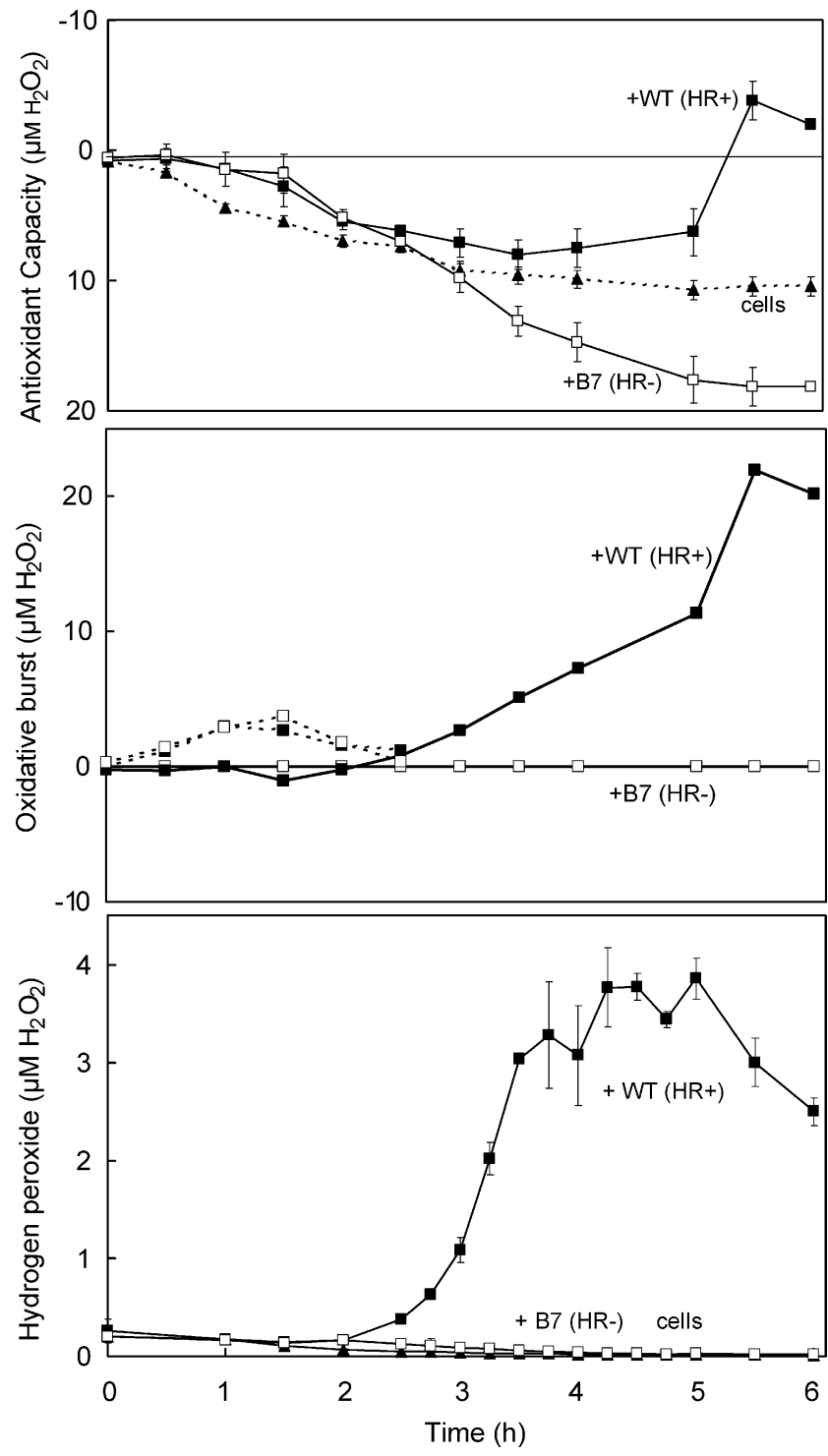

Fig. 2. Monitoring extracellular oxidative metabolism in potato suspension cells, $0.05 \mathrm{~g} \mathrm{ml}^{-1}$, treated with $P$. syringae pv. syringae strains, $2 \times$ $10^{7} \mathrm{cfu} \mathrm{ml}^{-1}$. (A) Determination of extracellular antioxidant capacity in $0.4 \mathrm{ml}$ samples by addition of $20 \mu \mathrm{M}$ hydrogen peroxide to suspension samples and measurement of the unreacted $\mathrm{H}_{2} \mathrm{O}_{2}$ by luminol-dependent chemiluminescence. Units are expressed in $\mu \mathrm{M} \mathrm{H}_{2} \mathrm{O}_{2}$ equivalents. (B) Detection of the oxidative stress in WT $(\mathrm{HR}+)$ treated cells by comparison to B7 (HR - ) treated cells (solid lines). Detection of the oxidative stress during the first $2 \mathrm{~h}$ by comparing both bacteria treatments to untreated cells (dotted line; $\square$, WT $(\mathrm{HR}+)$; $\square$, B7 $(\mathrm{HR}-)$ ). Units are expressed in $\mu \mathrm{M}$ $\mathrm{H}_{2} \mathrm{O}_{2}$ equivalents. (C) Detection of free extracellular $\mathrm{H}_{2} \mathrm{O}_{2}$ in $0.45 \mathrm{ml}$ samples using luminol-dependent-chemiluminescence. See Section 2 for details.

\subsection{Monitoring antioxidant capacity during plant/heat-killed bacterial interactions}

Fig. 3 shows the results of tobacco cells treated with heatkilled strain WT $(\mathrm{HR}+)$ bacteria, which previous studies [4] have shown elicits an oxidative burst. When heat-killed bacteria were added to cells at either 0 or $4.5 \mathrm{~h}$, an oxidative burst could be detected. The first burst, $0 \mathrm{~h}$, occurred 

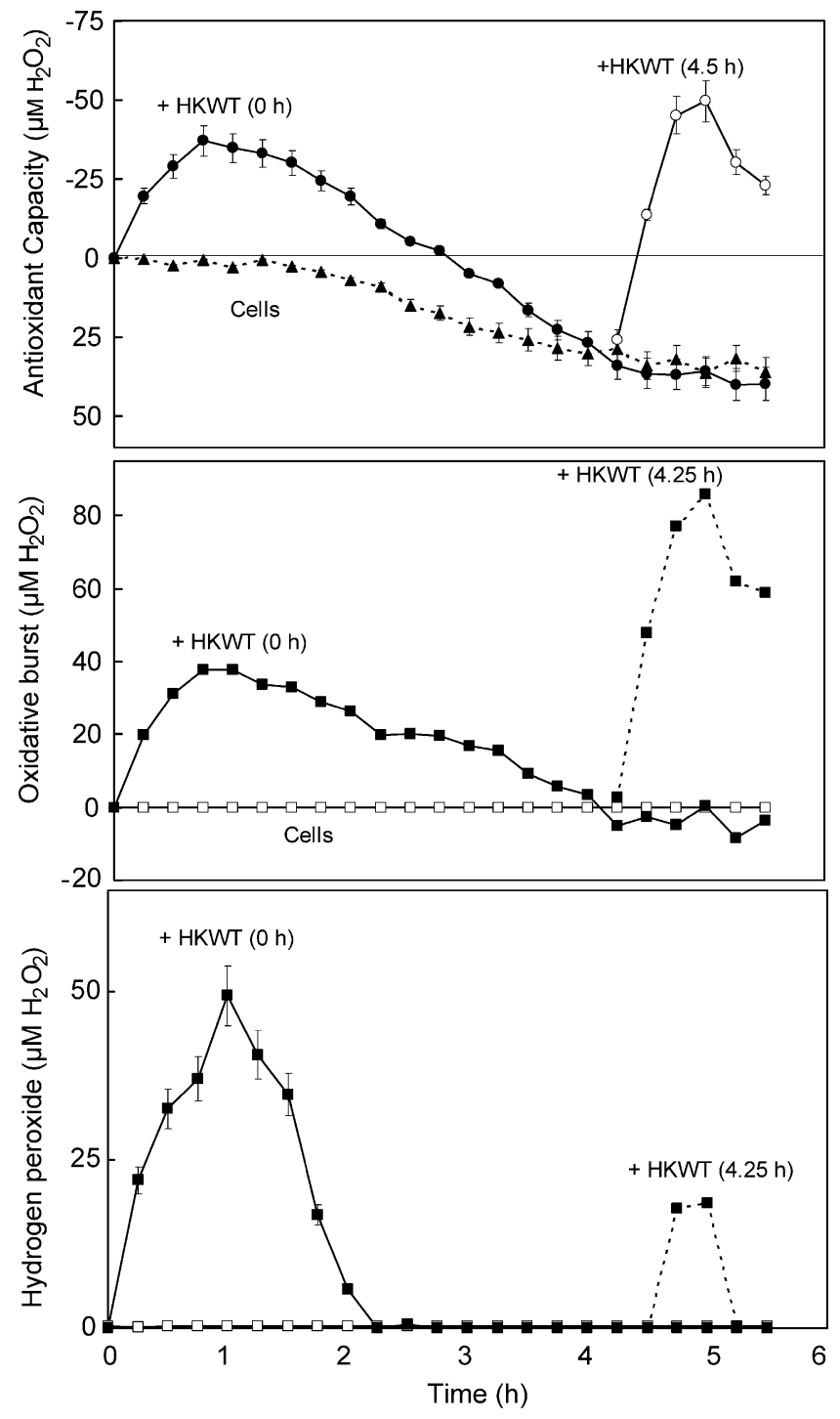

Fig. 3. Monitoring extracellular oxidative metabolism in tobacco suspension cells, $0.05 \mathrm{~g} \mathrm{ml}^{-1}$, treated with heat-killed $P$. syringae pv. syringae strain WT $(\mathrm{HR}+)$ added at 0 or $4.25 \mathrm{~h}$. (A) Determination of extracellular antioxidant capacity by addition of $50 \mu \mathrm{M}$ hydrogen peroxide to suspension samples and measurement of the unreacted $\mathrm{H}_{2} \mathrm{O}_{2}$ by luminol-dependent chemiluminescence. (B) Detection of the oxidative stress in HKWT-treated cell suspensions using untreated cells as a control. (C) Detection of free extracellular $\mathrm{H}_{2} \mathrm{O}_{2}$ in the suspension cells. Units are expressed in $\mu \mathrm{M} \mathrm{H}_{2} \mathrm{O}_{2}$ equivalents.

immediately and peaked within an hour, after which the antioxidant capacity began to increase as extracellular antioxidants began to accumulate (Fig. 3A). The rate of accumulation was faster than untreated cells and by $4 \mathrm{~h}$ both untreated and treated cells had similar antioxidant capacities. Addition of heat-killed bacteria to untreated cells after $4.5 \mathrm{~h}$ also caused an immediate oxidative burst that peaked within an hour (Fig. 3A). Comparison of the 0 and $4.5 \mathrm{~h}$ treatments to untreated cells suggests that more $\mathrm{H}_{2} \mathrm{O}_{2}$ was produced by the $4.5 \mathrm{~h}$ response, $90 \mu \mathrm{M}$, than the burst at $0 \mathrm{~h}, 40 \mu \mathrm{M}$ (Fig. 3B).
In contrast, direct detection of free $\mathrm{H}_{2} \mathrm{O}_{2}$ suggests that the oxidative burst at $0 \mathrm{~h}, 45 \mu \mathrm{m}$, was greater than the $4.5 \mathrm{~h}$ burst, $18 \mu \mathrm{M}$ (Fig. 3C). This can be explained by the lower concentration of extracellular antioxidants at $0 \mathrm{~h}$ and therefore, the lower rates of scavenging during the first burst. The higher concentrations of extracellular phenolics at $4.5 \mathrm{~h}$ scavenge the $\mathrm{H}_{2} \mathrm{O}_{2}$ as it is being produced so that the concentration of free $\mathrm{H}_{2} \mathrm{O}_{2}$ remains lower. In addition as mentioned above, it appears that the luminol-dependent detection of $\mathrm{H}_{2} \mathrm{O}_{2}$ requires the luminol to compete with extracellular phenolics if present.

\subsection{Parameters affecting the assay}

The assay is based upon the peroxidase-dependent chemiluminescent reaction of luminol with $\mathrm{H}_{2} \mathrm{O}_{2}$. Fig. 4A shows a diagrammatic simplification of the enzyme reaction, which is complex and the subject of many mechanistic studies.[7,14,18] In reaction a, peroxidase (POX) is oxidized by $\mathrm{H}_{2} \mathrm{O}_{2}$ and loses two electrons. In each of the next two reactions, peroxidase gains back one electron from a donor substrate, which in this study would be either extracellular antioxidant or luminol. If the electron donor is luminol, light is generally produced from the unstable oxidized product $\left(\mathrm{L}^{*}\right)$. We used a luminometer to measure the chemiluminescence, which corresponds to the near-steady state concentration of oxidized luminol, produced during the first $20 \mathrm{~s}$ of the reaction (Fig. 4B insert).

Under the conditions described here with $\mathrm{H}_{2} \mathrm{O}_{2}$ concentrations generally less than $100 \mu \mathrm{M}$ and other assay reactants constant, the peak or maximum value of chemiluminescence is directly proportional to the $\mathrm{H}_{2} \mathrm{O}_{2}$ concentration (Fig. 4B). The extracellular antioxidant in suspension cells will reduce the chemiluminescence by scavenging of $\mathrm{H}_{2} \mathrm{O}_{2}$ (Fig. 4C). A final concentration of $50 \mu \mathrm{M} \mathrm{H} \mathrm{H}_{2} \mathrm{O}_{2}$ was added to tobacco suspensions that had been incubated for increased lengths of time and therefore contained increased amounts of antioxidant. The antioxidants, via endogenous peroxidase, reduce the hydrogen peroxide available for reaction with the luminol (Fig. 4C).

Slight variations in the concentration of luminol used in the present study, $170 \mu \mathrm{M}$, had minimal effect on the peak value of chemiluminescence under the current assay conditions (Fig. 4D).

The amount of chemiluminescence produced by this assay is also proportional to the peroxidase concentration as shown here with luminol, $170 \mu \mathrm{M}$, and $\mathrm{H}_{2} \mathrm{O}_{2}, 10 \mu \mathrm{M}$, held constant (Fig. 4E). Because suspension cells contain endogenous cell wall peroxidase this must be considered for each cell line. Ideally the exogenous peroxidase should provide the majority of the enzyme for luminol oxidation to over shadow changes in endogenous peroxidase levels that may occur (Fig. 5). The traditional guaiacol-peroxidase reaction was adapted as described in the Section 2 to provide an estimation of the total extracellular peroxidase in cell suspensions including both soluble and cell wall bound enzyme. Using 
A
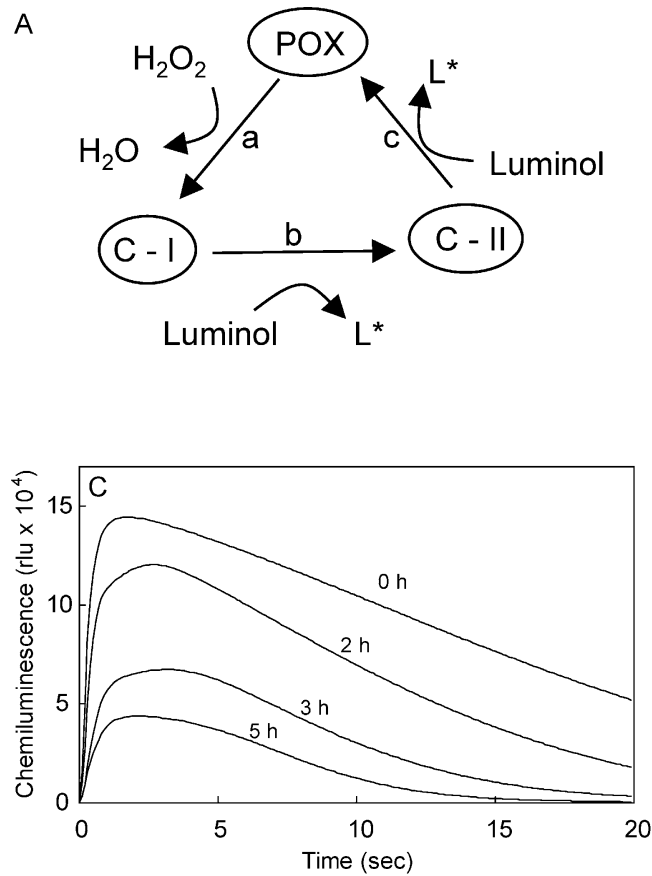
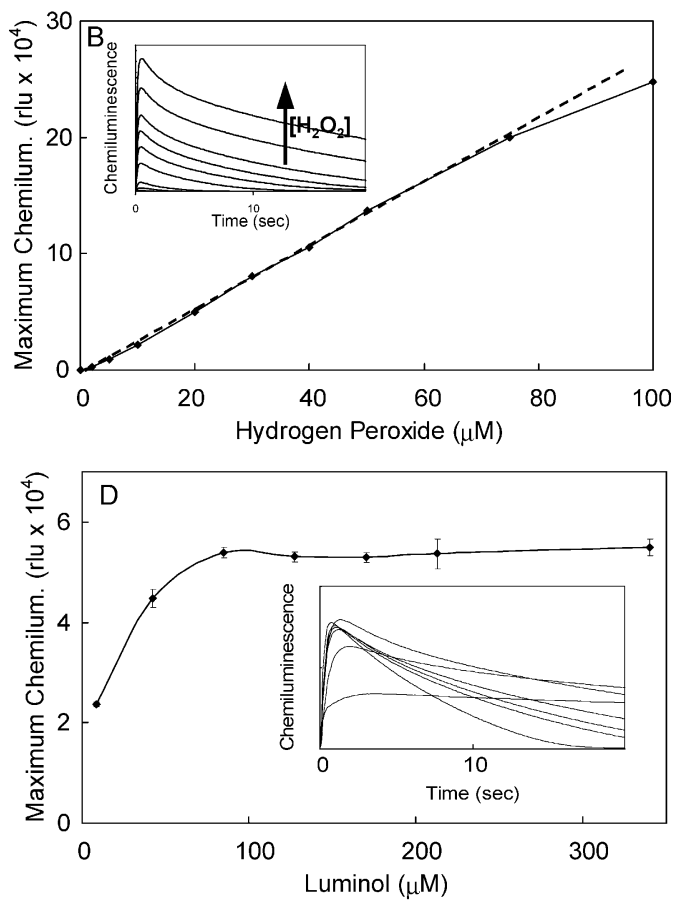

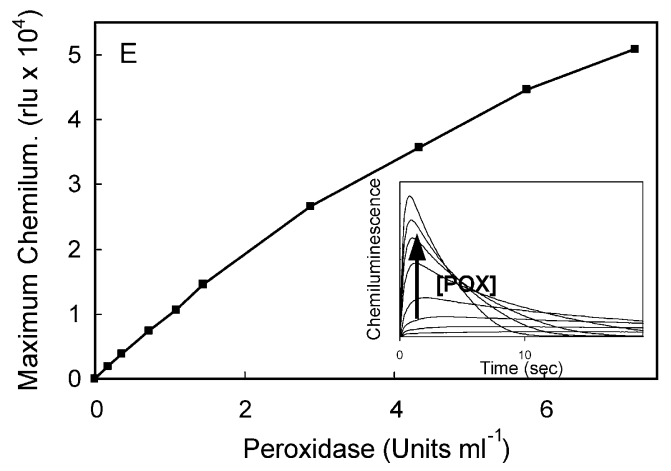

Fig. 4. The effect of various parameters on the luminol-dependent chemiluminescence reaction. (A) The three step peroxidase reaction: a, with the loss of 2 electrons, the native enzyme (POX) is oxidized to Compound I (C-I); b and c, C-I is reduced to Compound II (C-II) and subsequently back to POX, when it receives electrons from luminol. The loss of an electron by luminol produces an exited state $\left(\mathrm{L}^{*}\right)$ that ultimately produces light. (B) The hydrogen peroxide concentration is varied in the presence of $170 \mu \mathrm{M}$ luminol and $2.88 \mathrm{U} \mathrm{ml}^{-1}$ peroxidase per sample. The peak value produced during a $20 \mathrm{~s}$ reaction (insert) is plotted. (C) Chemiluminescence production when $50 \mu \mathrm{M} \mathrm{H}_{2} \mathrm{O}_{2}$, plus $170 \mu \mathrm{M}$ luminol and $2.88 \mathrm{U} \mathrm{ml}^{-1}$ peroxidase, are added to tobacco cells that have been incubated in assay buffer for $0-5 \mathrm{~h}$. (D) The luminol concentration is varied in the presence of hydrogen peroxide, $20 \mu \mathrm{M}$, and peroxidase, $2.88 \mathrm{U}$ ml ${ }^{-1}$. The peak value produced during a $20 \mathrm{~s}$ reaction (insert) is plotted. (E) The peroxidase concentration is varied in the presence of $170 \mu \mathrm{M}$ luminol and $10 \mu \mathrm{M}$ hydrogen peroxide. The peak value produced during a $20 \mathrm{~s}$ reaction (insert) is plotted.

potato and tobacco suspension cells it was apparent that peroxidase activity more than doubled over the 5-6 h monitoring period (Fig. 5). The increase in peroxidase was similar in untreated or bacteria treated cells for both potato and tobacco. The final endogenous peroxidase levels for potato and tobacco cells accounted for 5 and $10 \%$, respectively, of the total peroxidase activity utilized in the luminol dependent assay. Bacterial pathogens at concentrations used in these experiments contributed less than $1 \%$ of the peroxidase activity. Therefore, when comparing various treatments, the slight changes in endogenous peroxidase should not greatly influence the results.

The production of phenolics and other antioxidants such as ascorbic acid in suspension cells can substantially affect the redox status of the extracellular region. The method described here provides a relatively simple and non-invasive means to quantify the extracellular antioxidants present in cell suspensions. In addition, by accounting for changes in the concentration of these antioxidants, this method can provide a better estimate of the timing and magnitude of oxidative bursts that may occur when cell suspensions are treated with pathogens or pathogen-related elicitors. The technique avoids the need to directly detect reactive oxygen species and accounts for scavenging that may have occurred. Variations of this concept can be used to detect oxidative events in other scenarios such as infection drops or intracellular fluid. 


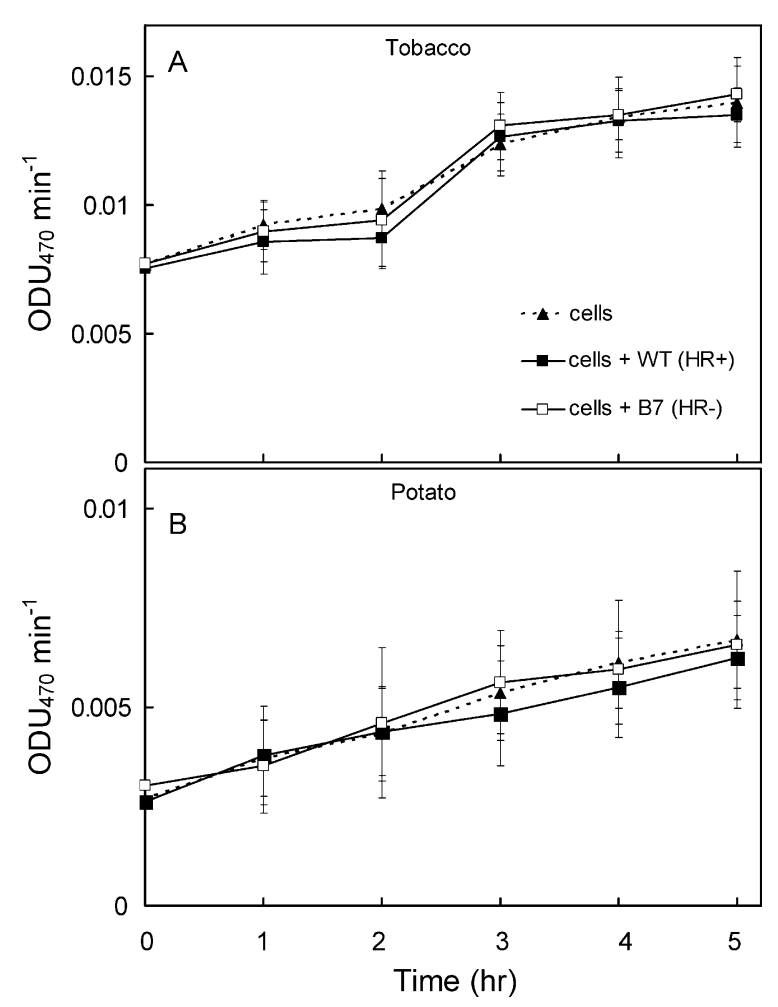

Fig. 5. Monitoring extracellular peroxidase activity in tobacco and potato suspension cells treated with with $P$ syringae pv. syringae strains, $2 \times$ $10^{7} \mathrm{cfu} \mathrm{ml}^{-1}$ samples were incubated with guaiacol and $\mathrm{H}_{2} \mathrm{O}_{2}$ for $15 \mathrm{~min}$, $\mathrm{pH}$ 6. The $\mathrm{OD}_{470}$ of the supernatant was determined every 2 min and the $\mathrm{OD}_{470} \mathrm{~min}^{-1}$ determined See Section 2 for details.

\section{Acknowledgements}

We would like to thank Ophrah Dawson and Sarah Waterworth for their excellent technical assistance.

\section{References}

[1] Baker CJ, Mock N, Deahl KL, Bailey B, Roberts DP. Oxidative metabolism in plant/bacteria interactions: characterization of the oxygen uptake response of bacteria. Physiol Mol Plant Pathol 2001; 59:17-23.

[2] Baker CJ, O'Neill NR, Deahl KL, Lydon J. Continuous production of extracellular antioxidants in suspension cells attenuates the oxidative burst detected in plant microbe interactions. Plant Physiol Biochem 2002;40:641-4.

[3] Baker CJ, Oneill NR, Keppler LD, Orlandi EW. Early responses during plant-bacteria interactions in tobacco cell suspensions. Phytopathology 1991;81:1504-7.
[4] Baker CJ, Orlandi EW, Deahl KL. Oxygen metabolism in plant/bacteria interactions: characterization of the oxygen uptake response of plant suspension cells. Physiol Mol Plant Pathol 2000;57:159-67.

[5] Bolwell G, Davies D, Gerrish C, Auh CK, Murphy T. Comparative biochemistry of the oxidative burst produced by rose and French bean cells reveals two distinct mechanisms. Plant Physiol 1998;116: 1379-85.

[6] Chong J, Pierrel MA, Atanassova R, Werck-Reichhart D, Fritig B, Saindrenan P. Free and conjugated benzoic acid in tobacco plants and cell cultures induced accumulation upon elicitation of defense responses and role as salicylic acid precursors. Plant Physiol 2001; 125:318-28.

[7] Cormier MJ, Prichard PM. An investigation of the mechanism of the luminescent peroxidation of luminol by stopped flow techniques. J Biol Chem 1968;243:4706-14.

[8] Delledonne M, Zeier J, Marocco A, Lamb C. Signal interactions between nitric oxide and reactive oxygen intermediates in the plant hypersensitive disease resistance response. Proc Natl Acad Sci USA 2001;98:13454-9.

[9] Desikan R, Mackerness SAH, Hancock JT, Neill SJ. Regulation of the arabidopsis transcriptome by oxidative stress. Plant Physiol 2001;127: $159-72$.

[10] Franke R, Fry SC, Kauss H. Low-molecular-weight precursors for defense-related cell wall hydroxycinnamoyl esters in elicited parsley suspension cultures. Plant Cell Rep 1998;17:379-83.

[11] Glazener J, Orlandi EW, Harmon GL, Baker CJ. An improved method for monitoring active oxygen in bacteria-treated suspension cells using luminol-dependent chemiluminescence. Physiol Mol Plant Pathol 1991;39:123-33.

[12] Legendre L, Rueter S, Heinstein PF, Low PS. Characterization of the oligogalacturonide-induced oxidative burst in cultured soybean (Glycine max) cells. Plant Physiol 1993;102:233-40.

[13] Levine A, Tenhaken R, Dixon R, Lamb C. $\mathrm{H}_{2} \mathrm{O}_{2}$ from the oxidative burst orchestrates the plant hypersensitive disease resistance response. Cell 1994;79:583-93.

[14] Lind J, Merenyi G, Eriksen TE. Chemiluminescence mechanism of cyclic hydrazides such as luminol in aqueous solutions. J Am Chem Soc 1983;105:7655-61.

[15] Lu HG, Higgins VJ. The effect of hydrogen peroxide on the viability of tomato cells and of the fungal pathogen Cladosporium fulvum. Physiol Mol Plant Pathol 1999;54:131-43.

[16] Mehlhorn H, Lelandais M, Korth HG, Foyer CH. Ascorbate is the natural substrate for plant peroxidases. FEBS Lett 1996;378:203-6.

[17] Pignocchi C, Foyer CH. Apoplastic ascorbate metabolism and its role in the regulation of cell signaling. Curr Opin Plant Biol 2003;6: 379-89.

[18] Roswell DF, White EH. The chemiluminescence of luminol and related hydrazides. Methods Enzymol 1978;57:409-23.

[19] Sanchez M, Queijeiro E, Revilla G, Zarra I. Changes in ascorbic acid levels in apoplastic fluid during growth of pine hypocotyls effect on peroxidase activities associated with cell walls. Physiologia Plantarum 1997;101:815-20.

[20] Takahama U. Ascorbic acid-dependent regulation of redox levels of chlorogenic acid and its isomers in the apoplast of leaves of Nicotiana tabacum L. Plant Cell Physiol 1998;39:681-9. 